\title{
Identification of ubiquitin in bovine milk and its growth inhibitory effects on human cancer cell lines
}

\author{
C. Freiburghaus,${ }^{* 1}$ C. Welinder, † U. Tjörnstad, $\ddagger$ H. Lindmark-Månsson, $\S$ M. Paulsson, ${ }^{*}$ and S. Oredsson $\ddagger$ \\ *Department of Food Technology, Engineering and Nutrition, Lund University, PO Box 124, 22100 Lund, Sweden \\ †Department of Oncology, Lund University, Barngatan 2B, 22185 Lund, Sweden \\ ‡Department of Cell and Organism Biology, Lund University, Helgonavägen 3b, 22362 Lund, Sweden \\ §Swedish Dairy Association, Scheelevägen 17, 22370 Lund, Sweden
}

\section{ABSTRACT}

Bovine milk is associated with improved health and reduced risk of several diseases, among them cancer. Milk is a complex mixture of known and unknown components. The components and the mechanisms that contribute to the cancer-preventive effects are largely unknown. We set out to find new peptides in milk and identified ubiquitin (Ub) using matrix-assisted laser desorption ionization-time of flight mass spectrometry and Western blot. Using quantitative Western blot, we estimated the Ub concentration to be about 0.003 $\mu \mathrm{mol} / \mathrm{L}$ in milk. We then decided to investigate the effect of treating human colon cancer $\mathrm{CaCo}-2$ cells with $\mathrm{Ub}$, using higher concentrations than in milk. CaCo-2 cells treated with 0.02 to $2.0 \mu \mathrm{mol} / \mathrm{L} \mathrm{Ub}$ showed significantly decreased proliferation compared with untreated control cells. A higher growth inhibitory effect than in CaCo-2 cells was found in the neuroblastoma cell line SH-SY5Y treated with 0.02 to $0.2 \mu \mathrm{mol} / \mathrm{L}$ Ub. A bromodeoxyuridine DNA flow cytometric method was used to study cell cycle kinetics in Ub-treated $\mathrm{CaCo}-2$ cells. The data point toward a prolongation of the $\mathrm{G}_{1}$ phase. The levels of several cell cycle regulatory proteins were affected. Our data point to Ub possibly being one of the components in milk reducing the risk of cancer.

Key words: ubiquitin, bovine milk, growth inhibitory effect, cancer cell

\section{INTRODUCTION}

Milk consumption has in several studies been linked to improved health (World Cancer Research Fund/ American Institute for Cancer Research, 2007; Elwood et al., 2008). For patients suffering from obesity, a reduction of metabolic syndrome and heart disease has been observed (Elwood et al., 2008). Evidence has been raised that suggests reduced diabetes incidence is

Received November 3, 2009.

Accepted March 17, 2010

${ }^{1}$ Corresponding author: catja.freiburghaus@food.lth.se linked to consumption of dairy foods (Choi et al., 2005; Liu et al., 2006). In addition, several epidemiological studies have linked milk consumption to a reduced risk of numerous cancers, among them colon cancer (Cho et al., 2004; World Cancer Research Fund/American Institute for Cancer Research, 2007). Milk proteins and peptides have been shown to affect the systems governing digestion, nerve response, and immune response (Korhonen and Pihlanto, 2006). These dietary proteins and peptides, with a specific effect that goes beyond nutrient supply, are called bioactive peptides and proteins (Schrezenmeir et al., 2000). Many of the bioactive peptides are encrypted in intact molecules and are released by enzyme digestions of food components (Möller et al., 2008).

Bovine milk is estimated to contain more than 100,000 components; most of the peptides and minor proteins are unidentified or incompletely characterized. Although several new proteins in bovine milk have been reported, identified by matrix-assisted laser desorption ionization-time of flight mass spectrometry (MALDITOF MS) and direct liquid chromatography-mass spectrometry, there are plenty more to discover (Smolenski et al., 2007; Fong and Norris, 2009). In this study, peptides and proteins (10 kDa and smaller) in bovine milk were separated by electrophoresis, and MALDITOF-MS was used to identify them. One new peptide identified was ubiquitin (Ub), with a molecular weight of approximately $8.6 \mathrm{kDa}$. The presence of $\mathrm{Ub}$ in bovine milk was confirmed by Western blot.

Ubiquitin, which to the best of our knowledge has not previously been reported in milk, is normally present in the cytoplasm and nucleus of all eukaryotic cells, with varying concentrations in different types of cells. The most well-known function of the 76-AA-long peptide is its conjugation in multi-Ub chains with different cellular proteins as a signal for degradation of the targeted proteins by the $26 \mathrm{~S}$ proteasome (Hershko and Ciechanover, 1992). The Ub-mediated proteolysis is a major pathway for selective protein degradation and it is involved in a variety of cellular processes, such as stress response, cell cycle regulation, gene expression, and apoptosis 
(Takada et al., 1997). Also, extracellular proteins are subjected to ubiquitination (e.g., defective mammalian spermatozoa are ubiquitinated for degradation as part of an active sperm quality control; Baska et al., 2008). This evolutionarily well-preserved polypeptide has also been reported to occur extracellulary (Goldstein et al., 1975), but data on the potential biological functions of extracellular Ub are rare.

Epidemiological studies as well as animal studies indicate that a reduced risk of cancer is linked to milk consumption (Gill and Cross, 2000; Perdigón et al., 2002; Cho et al., 2004; Wakabayashi et al., 2006; World Cancer Research Fund/American Institute for Cancer Research, 2007). Studies on the mechanism by which milk reduces the risk of cancer and whether milk can have an effect on cancer growth are therefore imperative. Cancer development and progression are linked to cell proliferation. In our project, we focused on investigating the effect of milk components on cell proliferation. As a primary model system we used the human CaCo-2 colon cancer cell line. Colon cancer is currently one of the leading causes of cancer deaths in the Western world, and the disease is also reported to be rapidly increasing in less-developed parts of the world (World Cancer Research Fund/American Institute for Cancer Research, 2007). Cancer is a disease that develops over a long time period, during which the control of cell division is slowly impaired during each round of cell division. Colon cancer commonly starts as a benign tumor or polyp in the intestine, which over time may develop into a malignant tumor (Lynch and de la Chapelle, 2003).

We have previously investigated the effect of the bran-derived hydroxycinnamic acids, ferulic acid and para-coumaric acid (Janicke et al., 2005), as well as the milk-derived lactoferricin on cell cycle progression and cell proliferation in CaCo-2 cells trying to deduce molecular mechanisms. Lactoferricin treatment prolonged the cell cycle by elongating the $\mathrm{S}$ (synthesis) phase, thereby reducing cell proliferation of the human $\mathrm{CaCo}-$ 2 colon cancer cell line (Freiburghaus et al., 2009). In the present study, we investigated the effects of bovine Ub on cell proliferation and cell cycle progression in CaCo-2 cells. Additional studies were performed on the human neuroblastoma cell line SH-SY5Y.

\section{MATERIALS AND METHODS}

\section{Filtration of Milk Samples and Removal of Lactose by Dialysis}

Nonhomogenized milk (Skånemejerier, Malmö, Sweden) was used in the search for peptides. Milk samples were centrifuged at $1,500 \times g$ for $20 \mathrm{~min}$ and the fat layer was removed. Filtration with Pellicon XL (Millipore Co., Bedford, MA) was performed according to instructions from the manufacturer. The cut-off between proteins and peptides was set to a size of 10 kDa. Float-a-lyzer (Spectrum Laboratories Inc., Rancho Dominguez, CA) with a cut-off of 500 Da was used for dialysis to remove lactose. Dialysis was performed according to the manufacturer's protocol. Freeze drying (Hetosicc, Heto, Birkeröd, Denmark) was performed until the whole sample was completely dry. This powder was used for peptide mass fingerprinting and peptide confirmation with Western blot.

\section{Peptide Mass Fingerprinting}

Samples of milk powder prepared as described above $(50 \mu \mathrm{g})$ were loaded to a 10-well $16 \%$ Tricine gel (Invitrogen, Carlsbad, CA) and run at $125 \mathrm{~V}$ for 90 min using Tricine SDS (Invitrogen) as running buffer. Proteins were visualized by staining with Coomassie Brilliant Blue (R-350). Selected proteins detected as bands on the gels were subjected to in-gel trypsin digestion. The bands $\left(\sim 1-2 \mathrm{~mm}^{2}\right.$ pieces $)$ of interest were washed and digested as described previously (Berggård et al., 2002). The purified peptides were eluted directly onto the sample target (Anchorchip target, Bruker Daltonik GmbH, Bremen, Germany), where $0.5 \mu \mathrm{L}$ of matrix, 2,5-dihydroxybenzoic acid $(10 \mathrm{mg} / \mathrm{mL}$ in $30 \%$ acetonitrile), had been added. Mass spectra of positively charged ions were recorded on a Bruker Reflex III instrument (Bruker Daltonics, Billerica, MA). The instrument was equipped with a delayed extraction ion source using a nitrogen laser at $337 \mathrm{~nm}$ and was operated in reflector mode at an accelerating voltage of $20 \mathrm{kV}$. A total of 160 to 210 single shot spectra were accumulated from each sample. The XMASS 5.0 and MS Biotools software packages provided by the manufacturer (Bruker Daltonik GmbH) were used for data processing. Known auto-proteolysis products from the trypsin were used for internal calibration. For protein identification, protein sequences in the SwissProt database were searched using Mascot software (Matrix Science Ltd., London, UK). Parameters specified in the search were taxa, Mamalians; missed cleavages, 1; peptide mass tolerance $\pm 0.1 \mathrm{Da}$; fixed modification, carbamidomethyl; and variable modification, oxidized methionine.

\section{Ub}

When discovered by Goldstein et al. (1975), Ub was presented as a highly conserved protein with extracellular actions. Because Ub is highly conserved, both between and within species, the Ub from red blood cells 
purchased for the study (U6253, 075K7405, SigmaAldrich Co., St. Louis, MO) is most likely similar to the Ub found in bovine milk. Ubiquitin from red blood cells was dissolved in PBS $(8 \mathrm{~g} / \mathrm{L}$ of $\mathrm{NaCl}, 0.2 \mathrm{~g} / \mathrm{L}$ of $\mathrm{KCl}, 1.15 \mathrm{~g} / \mathrm{L}$ of $\mathrm{Na}_{2} \mathrm{HPO}_{4}, 0.2 \mathrm{~g} / \mathrm{L}$ of $\left.\mathrm{KH}_{2} \mathrm{PO}_{4} ; \mathrm{pH} 7.3\right)$ to give a stock solution of $100 \mathrm{mM}$, which was sterilefiltered $(0.2 \mu \mathrm{mol} / \mathrm{L}$, Bergman Labora, Stockholm, Sweden) before addition to the cell cultures. Aliquots of the stock solution were kept at $-20^{\circ} \mathrm{C}$ until use. The concentrations used are specified below for each experiment.

\section{Cell Culture}

The CaCo-2 cell line, purchased from American Type Culture Collection (HTB-37, Manassas, VA), was grown in RPMI1640 medium supplemented with penicillin $(100 \mathrm{U} / \mathrm{mL})$, streptomycin $(100 \mu \mathrm{g} / \mathrm{mL})$, nonessential AA $(1 \mathrm{mM})$, and 10\% (vol/vol) fetal calf serum (FCS) throughout this study. The SH-SY5Y cell line was purchased from American Type Culture Collection (CRL-2266) and grown in DMEM/Ham's F12 medium supplemented with penicillin $(100 \mathrm{U} / \mathrm{mL})$, streptomycin $(100 \mu \mathrm{g} / \mathrm{mL})$, nonessential AA $(1 \mathrm{mM})$, and $10 \%$ (vol/vol) FCS throughout this study. Growth medium components were purchased from Biochrom (Berlin, Germany), and tissue culture plastics were purchased from Nunc (Roskilde, Denmark). Cultures were grown in a humidified atmosphere of $95 \%$ air and $5 \% \mathrm{CO}_{2}$ at $37^{\circ} \mathrm{C}$. These conditions were kept unchanged throughout the study.

All experiments with CaCo-2 cells were performed within passages 8 to 40 . The cells were passaged twice a week and never allowed to reach confluency because that induces differentiation. Cells were seeded at a density of $2 \times 10^{4}$ cells in $0.2 \mathrm{~mL}$ of medium $/ \mathrm{cm}^{2}$ of cell culture vessel surface area.

The SH-SY5Y cells were routinely passaged twice a week for 60 passages. Cells were seeded at a density of $2 \times 10^{4}$ cells in $0.2 \mathrm{~mL}$ of medium $/ \mathrm{cm}^{2}$ of cell culture vessel surface area.

\section{Identification of Ub Using Western Blot}

For Western blot analysis, the freeze-dried milk powder was diluted in sample buffer $(100 \mu \mathrm{L} / 40 \mathrm{mg}$ of milk powder, $62.5 \mathrm{mM}$ Tris-HCl, pH 6.8, $20 \%$ glycerol, $2 \%$ SDS, $5 \% \beta$-mercaptoethanol), sonicated, and heated at $95^{\circ} \mathrm{C}$ for 6 min and put on ice immediately after. Aliquots containing $6 \mathrm{mg}$ of freeze-dried milk were loaded in the wells of precast SDS polyacrylamide gels $(12 \%$; Invitrogen). Purified bovine Ub (Sigma-Aldrich Co.) in various concentrations was used, both as a positive control and as a means to estimate the Ub concentration in milk. The stock solution of $100 \mu \mathrm{mol} / \mathrm{L}(856 \mu \mathrm{g} / \mathrm{mL})$ was diluted in sample buffer to concentrations of 0.02 , $0.2,0.5,2,5,10,25$, and $50 \mu \mathrm{mol} / \mathrm{L} \mathrm{Ub}(0.17,1.7,4.3$, 17, 43, 86, 214, and $428 \mu \mathrm{g} / \mathrm{mL}$ ). Electrophoresis was performed in XCell Surelock Mini-Cell electrophoresis system (Invitrogen) and subsequent blotting onto nitrocellulose membranes for $7 \mathrm{~min}$ at $20 \mathrm{~V}$ was performed using iBlot Dry Blotting System (Invitrogen). The membranes were then blocked with $5 \%$ BSA in $0.05 \%$ Tween-20 in PBS before overnight incubation with the primary antibody. Antibody against bovine Ub (sc8017) was purchased from Santa Cruz Biotechnology Inc. (Santa Cruz, CA). Advanced enhanced chemiluminescence protein detection reagent was used according to the manufacturer's protocol (Amersham Biosciences Ltd., Buckinghamshire, UK). The ChemiDoc XRS system (Bio-Rad Inc., Hercules, CA) was used for the imaging and the software Quantity One (Bio-Rad Inc.) was used for the analysis of the bands. The Ub content in bovine milk was estimated based on the intensity of the bands and related to the original protein content in the milk samples used for this study.

\section{Short and Long Time Effects on Cell Proliferation}

For the short time experiments, several replicate cultures, consisting of $0.25 \times 10^{6} \mathrm{CaCo}-2$ cells seeded into $5 \mathrm{~mL}$ medium in Petri dishes (5 $\mathrm{cm}$ diameter), were set up. To study the effect of Ub on cancer cell proliferation over a longer time period, several replicate cultures, consisting of $0.5 \times 10^{6}$ cells, were seeded in $5 \mathrm{~mL}$ of medium in cell culture flasks $\left(25 \mathrm{~cm}^{2}\right)$. After seeding, the cells were allowed to attach and grow for $24 \mathrm{~h}$ before addition of Ub. The concentrations used were 0.02 and $2.0 \mu \mathrm{mol} / \mathrm{L} \mathrm{Ub}$ in the short time experiment and 0.02 and $0.2 \mu \mathrm{mol} / \mathrm{L} \mathrm{Ub}$ in the long time experiment. The short time experiment was repeated 3 times, with triplicates of the Petri dishes used for each time point to be analyzed. At each time point, cells were harvested by trypsinization, after which the cell number was determined by counting in a hemocytometer (VWR International, West Chester, PA). The long time experiment stretched over 9 passages (5 wk). At each passage (every third day for $5 \mathrm{wk}$ ), cells were photographed, harvested by trypsinization, counted in a hemocytometer, and reseeded at the same density as above. The cells received the same treatment during each passage. The total amount of cells that theoretically had accumulated during the time period for 9 passages, calculated from the data of seeding 0.5 $\times 10^{6}$ cells at each passage, was presented as percentage of control. Thus, by using the cell number obtained at each passage of a culture that was seeded with $0.5 \times$ $10^{6}$ cells, we calculated the number of cells that would 
have been obtained if all cells were reseeded at a lower density at each passage. It is not physically feasible to reseed all cells at each passage because it requires larger and larger cell culture vessels at each passage and there is a limit to the size of cell culture vessels. The long time experiment was repeated 3 times with CaCo-2 cells and once with SH-SY5Y neuroblastoma cells. In each experiment, the growth of 3 independent cultures was followed.

\section{Cell Cycle Kinetics}

Cells were labeled with a final concentration of 5 $\mu \mathrm{mol} / \mathrm{L}$ bromodeoxyuridine (BrdUrd; Dako, Glostrup, Denmark) for $30 \mathrm{~min}$ at 24,48 , and $72 \mathrm{~h}$ of treatment with 0.02 or $2.0 \mu \mathrm{mol} / \mathrm{L} \mathrm{Ub}$. The labeling has previously been described in detail (Freiburghaus et al., 2009). After the BrdUrd labeling period, the medium was aspirated and the cultures were rinsed twice with RPMI1640 medium containing $0.5 \%$ FCS $\left(37^{\circ} \mathrm{C}\right)$. The cultures were then further incubated with complete medium $\left(37^{\circ} \mathrm{C}\right)$ containing the same addition of PBS or Ub as before BrdUrd labeling. Cells were harvested by trypsinization at 0 and $5 \mathrm{~h}$ postlabeling for one experiment and at $0,4,6,8,10$, and $12 \mathrm{~h}$ postlabeling for more extensive studies of cell cycle kinetics. Cells were pelleted by centrifugation at $700 \times g$ for $10 \mathrm{~min}$, resuspended, and fixed in ice-cold $70 \%$ ethanol. The samples were then stored at $-20^{\circ} \mathrm{C}$ until analysis. The experiment was repeated twice, with triplicates of the Petri dishes used for each time point to be analyzed.

\section{Flow Cytometric Analysis of BrdUrd and DNA Contents}

The staining of DNA and BrdUrd has been described in detail (Fredlund et al., 1994; Fredlund and Oredsson, 1997; Nasizadeh et al., 2005; Freiburghaus et al., 2009). The cells were analyzed with respect to DNA (red fluorescence) and BrdUrd (green fluorescence) content in a Cytograph System50-H flow cytometer (Ohio Instruments, Westwood, MA). For the computer analysis, Multi2D and Multicycle software programs (Phoenix Flow Systems, San Diego, CA) were used. The data were analyzed and calculations were made as described previously (Fredlund and Oredsson, 1997).

\section{Western Blot Analysis of Cellular Proteins}

Western blot analysis was performed as described previously (Freiburghaus et al., 2009). In short, after harvesting by trypsinization, the cell number was determined by counting in a hemocytometer. The cells were pelleted by centrifugation and stored at $-80^{\circ} \mathrm{C}$ before analysis. The cells were diluted in sample buffer $(300$ $\mu \mathrm{L} / 10^{6}$ cells, $62.5 \mathrm{~m} M$ Tris-HCl, $\mathrm{pH} 6.8,20 \%$ glycerol, $2 \%$ SDS, $5 \%$ ß-mercaptoethanol), sonicated, and heated at $95^{\circ} \mathrm{C}$ for 6 min and put on ice immediately after. Aliquots containing 50,000 cells were loaded in the wells of precast SDS polyacrylamide gels (12\%; Invitrogen). Electrophoresis was performed in XCell Surelock MiniCell electrophoresis system (Invitrogen) and subsequent blotting was performed using XCell blot module (Invitrogen). The membranes were then blocked with $5 \%$ dry milk in $0.05 \%$ Tween-20 in PBS for detection of total protein levels or $5 \%$ BSA in $0.05 \%$ Tween-20 in PBS for detection of phosphorylated proteins before overnight incubation with the primary antibody. Antibody against human cyclin E1 (sc-247) was purchased from Santa Cruz Biotechnology Inc. Antibodies against human cyclin A2 (554175), human cyclin B1 (554176), and human cyclin D1 (554180) were purchased from BD PharMingen (San Diego, CA). Antibodies against extracellular signal-regulated kinase 1/2 (ERK1/2; ab5430) and phosphorylated ERK1/2 (ab50011) were purchased from Abcam (Cambridge, UK). Horseradish peroxidase-conjugated goat anti-mouse immunoglobulin was used as a secondary antibody (P0447, Dako). Advanced enhanced chemiluminescence protein detection regent was used according to the manufacturer's protocol (Amersham Biosciences Ltd.). The ChemiDoc XRS system (Bio-Rad Inc.) was used for the imaging and the software Quantity One (Bio-Rad Inc.) was used for the analysis of the bands.

\section{Data Analysis and Statistical Analysis}

Two-tailed unpaired Student's $t$-test was used for the statistical evaluation of significance. Regression analysis was used to determine the length of the $\mathrm{G}_{2}+\mathrm{M}$ phase. Statistical analyses were performed in Microsoft Excel (2003, Microsoft Corp., Redmond, WA).

\section{RESULTS}

\section{Identification of Ub in Bovine Milk}

The existence of several previously known bovine milk proteins and peptides was confirmed by MALDI-TOF MS (Figure 1A; Table 1). Also, several low-molecular bands, which we were not able to indentify, appeared on the gel. In addition, Ub, a previously unknown component in bovine milk, was identified. This was also confirmed by Western blot (Figure 1B). By using purified $\mathrm{Ub}$ in different known concentrations as positive controls for Western blot, Ub concentrations in bovine milk could be estimated (Figure 2). The intensity of the $\mathrm{Ub}$ band in $6 \mathrm{mg} / 15 \mu \mathrm{L}$ of milk powder can be 
Table 1. Peptides and protein fragments identified in bovine milk using matrix-assisted laser desorption ionization-time of flight mass spectrometry (MALDI-TOF MS) ${ }^{1}$

\begin{tabular}{|c|c|c|c|c|c|c|}
\hline Item & $\begin{array}{l}\text { Peptide/protein } \\
\text { fragment }\end{array}$ & $\begin{array}{l}\text { Accession } \\
\text { no. }\end{array}$ & $\begin{array}{c}\text { Molecular } \\
\text { weight }(\mathrm{kDa})\end{array}$ & $\begin{array}{l}\text { Matched } \\
\text { peaks (n) }\end{array}$ & Score & $\begin{array}{c}\text { Sequence } \\
\text { coverage (\%) }\end{array}$ \\
\hline Band 1 & $\beta$-Lactoglobulin & P02754 & 20.3 & 10 & 126 & 39 \\
\hline Band 2 & $\alpha$-Lactalbumin & P00711 & 16.7 & 6 & 92 & 40 \\
\hline Band 3 & $\alpha$-Lactalbumin & P00711 & 16.7 & 7 & 113 & 68 \\
\hline Band 4 & $\alpha$-Lactalbumin & P00711 & 16.7 & 7 & 86 & 36 \\
\hline Band 5 & $\beta$-2-Microglobulin & P01888 & 13.8 & 4 & 60 & 41 \\
\hline Band 6 & Ubiquitin & P62990 & 8.6 & 5 & 82 & 57 \\
\hline
\end{tabular}

${ }^{1}$ Free peptides and peptides derived from proteins in nonhomogenized commercial bovine milk identified by MALDI-TOF MS. For protein identification, protein sequences in the SwissProt database were searched using Mascot software (Matrix Science Ltd., London, UK). Parameters specified in the search were taxa, Mamalians; missed cleavages, 1 ; peptide mass tolerance \pm 0.1 Da; fixed modification, carbamidomethyl; variable modification, oxidized methionine.

approximated to be $0.9 \mu \mathrm{mol} / \mathrm{L}(7.8 \mu \mathrm{g} / \mathrm{mL})$. Based on the dilution of the freeze-dried milk powder, the information above was used to estimate the Ub concentration in milk to be $0.003 \mu \mathrm{mol} / \mathrm{L}(26 \mathrm{ng} / \mathrm{mL})$. In addition to the Ub monomer $(8.6 \mathrm{kDa})$, several bands with molecular weights corresponding to Ub polymers were visible on the Western blot.

\section{Cell Proliferation}

CaCo- 2 cells treated with 0.02 or $2.0 \mu \mathrm{mol} / \mathrm{L} \mathrm{Ub}$ showed a lower cell number compared with untreated control cells after 1 to $6 \mathrm{~d}$ of treatment (Figure 3A). However, the growth inhibitory effect was small and significant differences were found only for treatment with $2.0 \mu \mathrm{mol} / \mathrm{L} \mathrm{Ub}$ for 4 to $6 \mathrm{~d}$.

In addition to the 1-wk proliferation study, cells were grown in the absence or presence of Ub for an extended period of time ( $5 \mathrm{wk}$ ) because this more resembles the exposure in vivo owed to recurrent dairy consumption. Experiments were carried out on CaCo-2 cells (Figure 3B) and also on the human neuroblastoma cell line SH-SY5Y (Figure 3C). For both cell lines, the effects on cell proliferation were prominent over a long time span, with a significant decrease in cell number for cells treated with 0.02 or $0.2 \mu \mathrm{mol} / \mathrm{L} \mathrm{Ub}$ compared with untreated control cells. The morphology of the cells was monitored microscopically throughout the
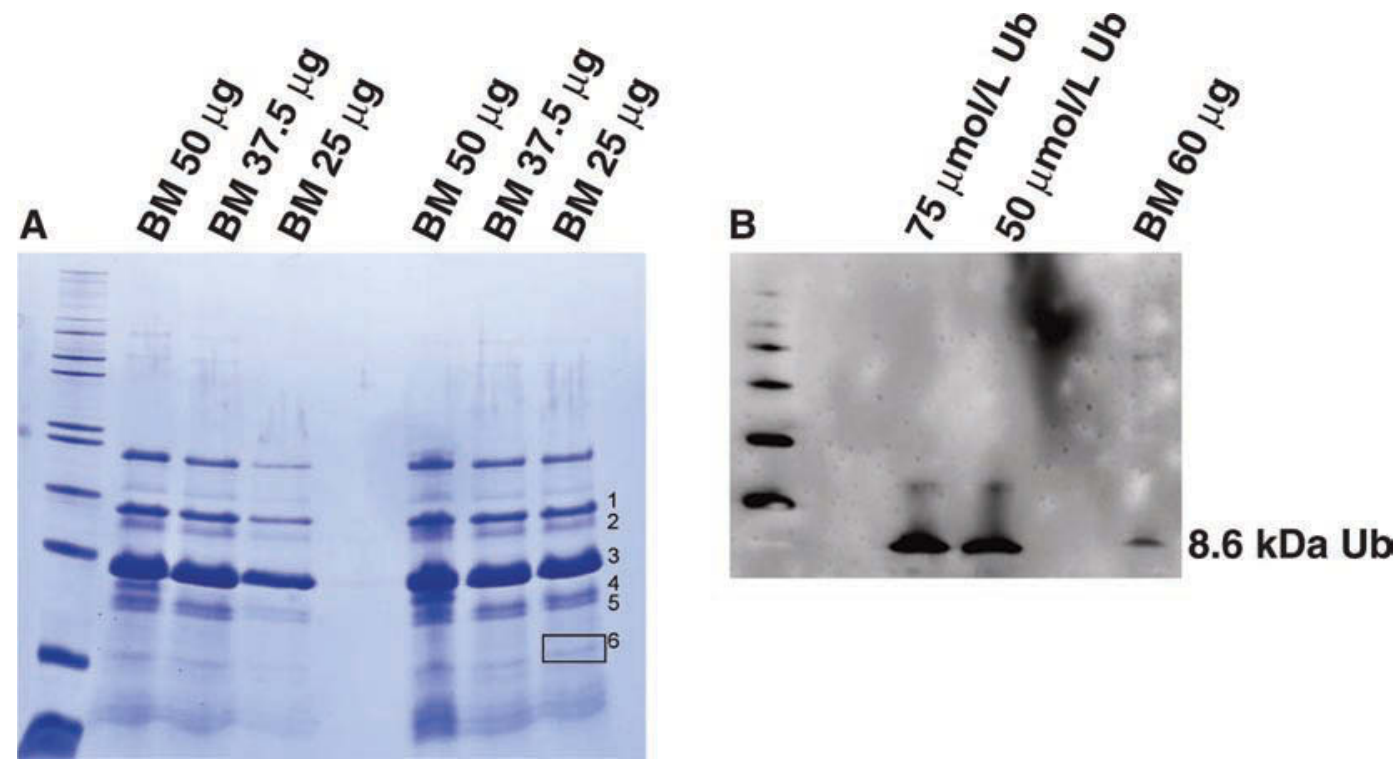

Figure 1. Detection of ubiquitin in bovine milk. A) Bovine milk was skimmed, filtered to remove molecules with molecular size over $10 \mathrm{kD}$, dialyzed to remove lactose, and freeze dried. The powder ( $\mu \mathrm{g}$ loaded shown in figure) was dissolved in sample buffer and run on 1-dimensional electrophoresis. The gel was dyed with Coomassie Blue. The different lanes are different dilutions of 2 samples. Bands marked 1 to 6 were extracted and identified with matrix-assisted laser desorption ionization-time of flight (Table 1). Band 6 was identified as ubiquitin. B) Ubiquitin in milk was also identified using Western blot. Pure ubiquitin (75 and $50 \mu \mathrm{mol} / \mathrm{L}$ ) was loaded on the same gel as a positive control. Color version available in the online PDF. 

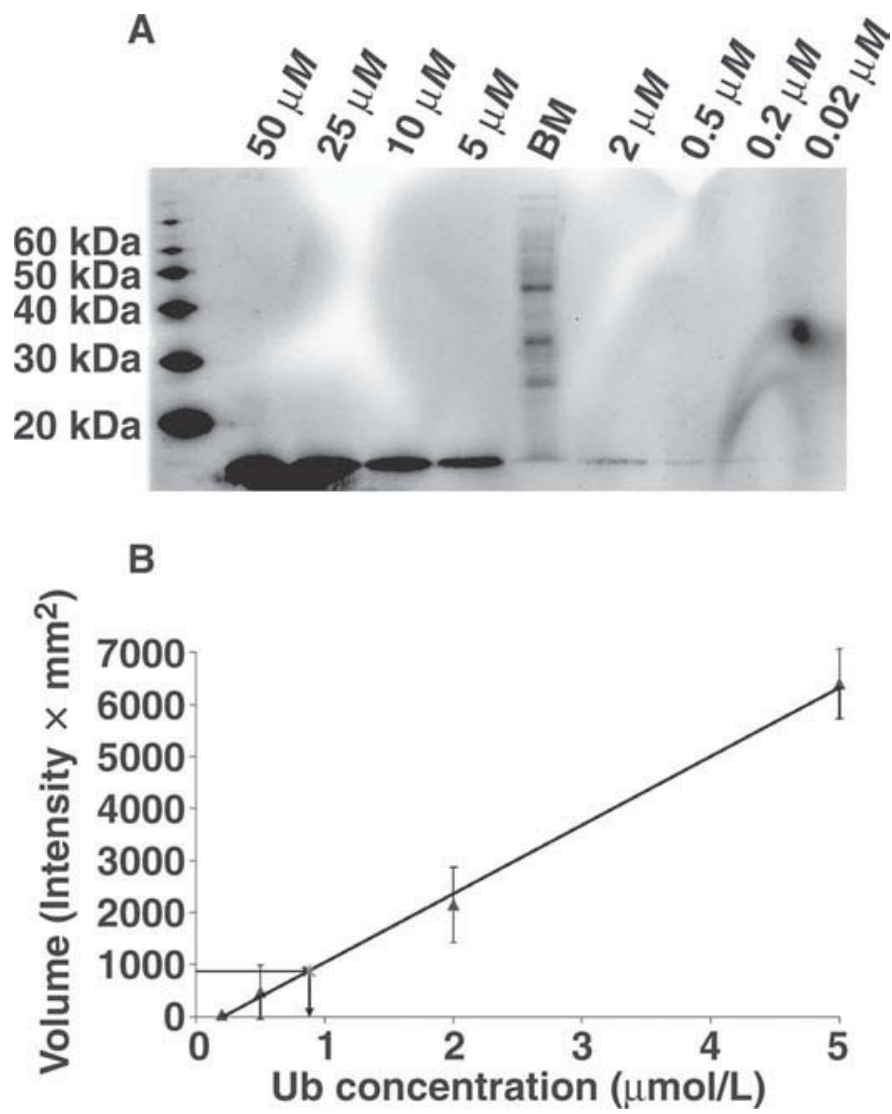

Figure 2. Quantitative Western blot to get a rough estimate of the ubiquitin concentration in milk. A) Electrophoresis was run with samples containing different concentrations of ubiquitin from bovine red blood cells and with a bovine milk sample. B) The bands in A were densitometrically scanned and a standard curve was drawn. The curve was used to get a rough estimate of the ubiquitin (Ub) concentration in milk (arrows). Taking dilution into account, the ubiquitin concentration in milk was calculated to $0.003 \mu \mathrm{mol} / \mathrm{L}$. Representative image shown for $\mathrm{n}=2$.

study; however, no morphological changes could be observed.

\section{Cell Cycle Kinetics}

Next, the effect of Ub treatment on the length of the $\mathrm{S}$ phase and the $\mathrm{G}_{2}+\mathrm{M}$ (gap $2+$ mitosis) phase and on the rate of $\mathrm{G}_{1}$ (gap 1)/S transition was investigated (Fredlund and Oredsson, 1997; Nasizadeh et al., 2005). Small but prominent effects on cell cycle kinetics may be revealed using a BrdUrd DNA flow cytometric method. The data in Table 2 show that there was no significant effect on the $\mathrm{S}$ phase after treatment with 0.02 and $2.0 \mu \mathrm{mol} / \mathrm{L} \mathrm{Ub}$ for 24,48 , or $72 \mathrm{~h}$. The rate of $\mathrm{G}_{1} / \mathrm{S}$ transition was studied by investigating the movement of BrdUrd-nonlabeled cells from the $\mathrm{G}_{1}$ phase into the S phase (Fredlund and Oredsson, 1997; Nasizadeh et al., 2005). Figure 4A shows the percentage decrease in the $G_{1}$ phase population, which is inversely correlated to the increase in the $\mathrm{S}$ phase population. The slopes of the lines indicate the rate of $\mathrm{G}_{1} / \mathrm{S}$ transition (i.e., the steeper the line, the higher the rate of $\mathrm{G}_{1} / \mathrm{S}$ transition). When no cells are entering the $\mathrm{S}$ phase, the line is horizontal. The rate of $\mathrm{G}_{1} / \mathrm{S}$ transition in CaCo-2 cells was not affected after $48 \mathrm{~h}$ of Ub treatment. During the postlabeling time, BrdUrd-labeled cells will progress through the $\mathrm{G}_{2}+\mathrm{M}$ phase and into the $\mathrm{G}_{1}$ phase of the next cell cycle; BrdUrd-labeled cells appear in the $\mathrm{G}_{1}$ phase when the minimum time period for the $G_{2}+M$ phase has passed. The percentage of BrdUrd-labeled divided cells in relation to the total number of BrdUrdlabeled cells was plotted in a graph to calculate the length of the $\mathrm{G}_{2}+\mathrm{M}$ phase (Fredlund and Oredsson, 1997; Nasizadeh et al., 2005; Figure 4B). The intercepts of the lines with the $\mathrm{x}$-axis are a measure of the length of the $\mathrm{G}_{2}+\mathrm{M}$ phase. The length of the $\mathrm{G}_{2}+\mathrm{M}$ phase in the $\mathrm{CaCo}-2$ cells was not significantly altered after 48 $\mathrm{h}$ of Ub treatment. Taken together, the BrdUrd DNA flow cytometric data show that Ub treatment does not affect the length of the $\mathrm{S}$ phase or $\mathrm{G}_{2}+\mathrm{M}$ phase, nor the $\mathrm{G}_{1} / \mathrm{S}$ transition. Thus, our notion is that there is a prolongation of the $G_{1}$ phase.

\section{Western Blot Analysis}

Because Ub treatment affected the proliferation rate, the expression of various cell cycle regulatory proteins was studied using Western blot. Our interpretation of the data is based on 4 or more independent experiments. The level of the nonphosphorylated ERK1/2 $44-\mathrm{kDa}$ protein was slightly higher than the level of the $42-\mathrm{kDa}$ protein; however, the $42-\mathrm{kDa}$ band was more phosphorylated (Figure 5A). The protein levels in ERK1/2 remained unchanged in cells grown in the presence of Ub compared with control cells, whereas the levels of phosphorylated ERK1/2 decreased slightly (Figure 5B). The levels of both cyclin D1 and cyclin E1 were significantly increased by $0.02 \mu \mathrm{mol} / \mathrm{L} \mathrm{Ub}$ compared with control cells. Treatment with $2.0 \mu \mathrm{mol} / \mathrm{L}$ Ub also resulted in increased cyclin D1 and E1 levels, although they were not significant. The cyclin A2 level was significantly increased for cells treated with both 0.02 and $2.0 \mu \mathrm{mol} / \mathrm{L} \mathrm{Ub}$. The level of cyclin B1, however, was decreased in cells treated with 0.02 and 2.0 $\mu \mathrm{mol} / \mathrm{L} \mathrm{Ub}$.

The Ub level in the cells was also investigated. Both the level of free Ub and the levels of Ub-conjugated proteins were increased in cells treated with Ub for $48 \mathrm{~h}$ compared with the untreated control cells (Figure 6).

\section{DISCUSSION}

The existence of bioactive peptides in bovine milk has been known for a long time, and numerous authors have 
Table 2. Effect of ubiquitin on the length of the $\mathrm{S}$ (synthesis) phase ${ }^{1}$

\begin{tabular}{lccc}
\hline $\begin{array}{l}\text { Treatment } \\
\text { time }(\mathrm{h})\end{array}$ & Control & $\begin{array}{c}0.02 \mu \mathrm{mol} / \mathrm{L} \\
\text { ubiquitin }\end{array}$ & $\begin{array}{c}2.0 \mu \mathrm{mol} / \mathrm{L} \\
\text { ubiquitin }\end{array}$ \\
\hline 24 & $13.6 \pm 1.2$ & $11.3 \pm 1.1$ & $12.8 \pm 1.1$ \\
48 & $13.9 \pm 1.2$ & $15.6 \pm 2.6$ & $15.3 \pm 3.1$ \\
72 & $12.1 \pm 0.1$ & $11.0 \pm 0.1$ & $11.2 \pm 0.2$ \\
\hline
\end{tabular}

${ }^{1}$ The length of the $\mathrm{S}$ phase in CaCo-2 cells grown in the absence or presence of 0.02 or $2.0 \mu \mathrm{mol} / \mathrm{L}$ ubiquitin for 24,48 , or $72 \mathrm{~h}(\mathrm{n}=6)$ from 2 independent experiments. Values are mean \pm SD.

described their relevance for human health (Clare and Swaisgood, 2000; Korhonen and Pihlanto, 2006; Mader et al., 2006; Haug et al., 2007; Elwood et al., 2008). High consumption of dairy foods have been shown to reduce the risk of metabolic syndrome, heart disease (Elwood et al., 2008), diabetes (Choi et al., 2005; Liu et al., 2006), and numerous cancers (Hjartåker et al., 2001; Cho et al., 2004; World Cancer Research Fund/ American Institute for Cancer Research, 2007).

To exert physiological effects, many bioactive peptides must be released from their precursor proteins and reach their active sites. Bioactive peptides can also exist freely in the milk. Although the knowledge of bioactive milk peptides is greatly appreciated and some peptides are produced commercially and used as ingredients in functional foods (Korhonen, 2009), the full extent of the biologically active components in our diet is still unrevealed.

Although several studies have been conducted to map the many different components in bovine milk (Korhonen and Pihlanto, 2006; Smolenski et al., 2007), much is still unrevealed. To the best of our knowledge, Ub has not previously been identified in bovine milk. In the present study, Ub in bovine milk was first identified using MALDI-TOF MS and then confirmed by Western blot. In human serum and cerebrospinal fluid, the Ub concentration was found to be $0.007 \mu \mathrm{mol} / \mathrm{L}(60 \mathrm{ng} /$ $\mathrm{mL}$ ) and $0.0025 \mu \mathrm{mol} / \mathrm{L}(20 \mathrm{ng} / \mathrm{mL})$, respectively (Majetschak et al., 2006). Our approximations using quantitative Western blot suggest that the Ub concentration in the used milk was about $0.003 \mu \mathrm{mol} / \mathrm{L}(26 \mathrm{ng} / \mathrm{mL})$. As a comparison, the level of lactoferrin in bovine milk was $1.28 \mu \mathrm{mol} / \mathrm{L}(0.1 \mathrm{mg} / \mathrm{mL}$; Wakabayashi et al., 2006). In our experiments we used somewhat higher concentrations than those found in milk to investigate whether extracellular Ub could have an effect at all. After an initial effect had been observed with $2.0 \mu \mathrm{mol} / \mathrm{L}$ Ub, long-term studies were performed with 0.02 or 0.2 $\mu \mathrm{mol} / \mathrm{L}$ concentrations, the former being only 10 times higher than in milk. Information about the peptide's journey after intake of milk, through the upper digestive system (esophagus and stomach) to the intestinal mucosa in the lower gastrointestinal tract (the small
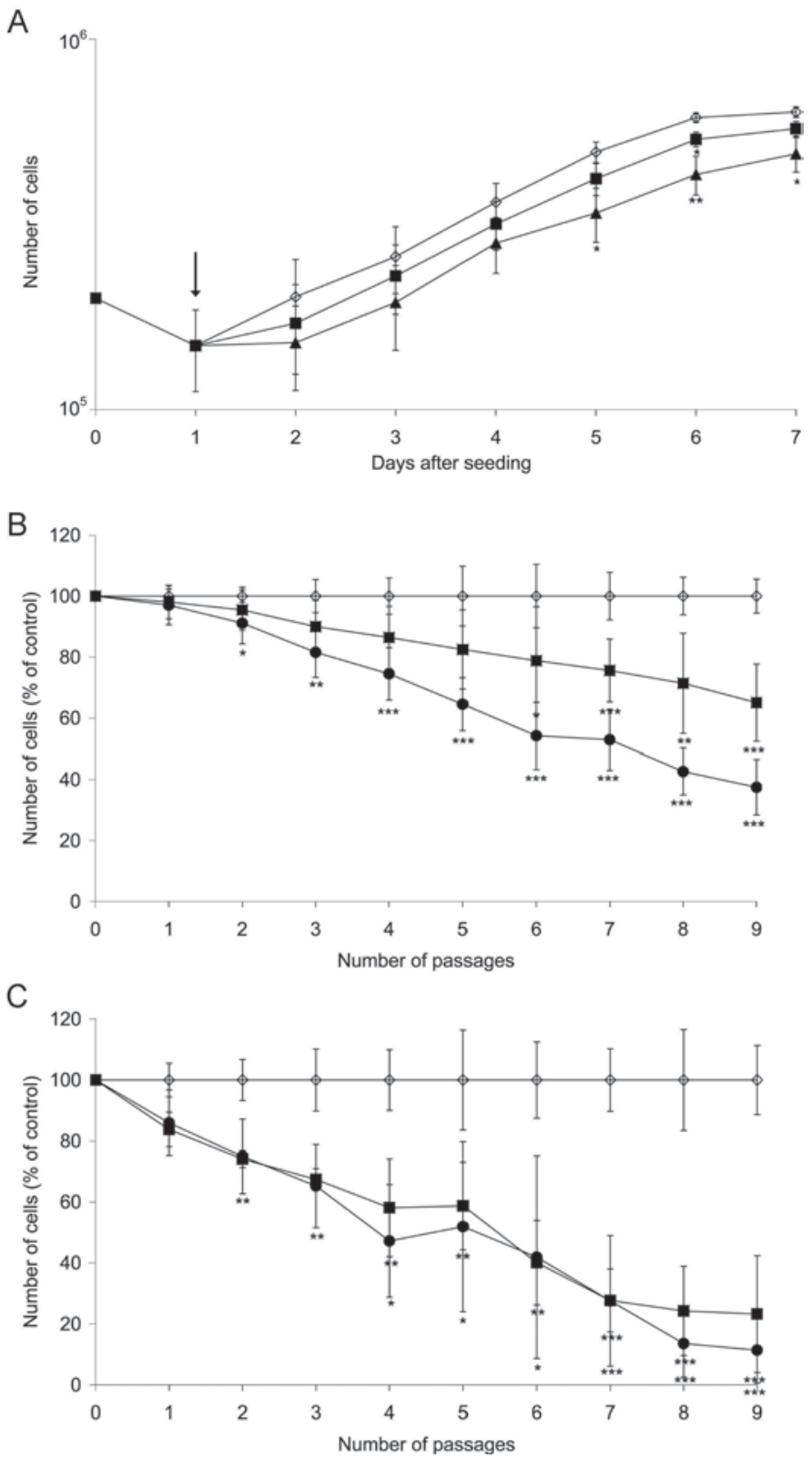

Figure 3. Ubiquitin reduced the rate of cell proliferation in $(\mathrm{A}, \mathrm{B})$ human colon cancer CaCo-2 cells and (C) in human neuroblastoma SH-SY5Y cells. A) Twenty-four hours after seeding of cells (arrow), ubiquitin was added to achieve the final concentrations of $0.02(\boldsymbol{\square})$ or $2.0(\Delta) \mu \mathrm{mol} / \mathrm{L}$. Control cells $(\diamond)$ received an equal volume of PBS. The cell number was determined by counting in a hemocytometer over $7 \mathrm{~d}$. B, C) For the experiments over 9 passages ( $5 \mathrm{wk}$ ), cells were treated with $0.02(\mathbf{\square})$ or $0.2(\bullet) \mu \mathrm{mol} / \mathrm{L}$ ubiquitin; the cell number is presented as percentage of that in the control $(\diamond)$. Control was set to $100 \%$. Symbols represent (A and B) mean \pm SEM for 9 independent cultures from 3 independent experiments and $(\mathrm{C})$ mean $\pm \mathrm{SD}$ for 3 independent cultures in 1 experiment. When not visible, bars are covered by the symbol. ${ }^{*} P<0.05$ compared with control; ${ }^{* *} P<0.01$ compared with control; ${ }^{* * *} P<0.001$ compared with control. 

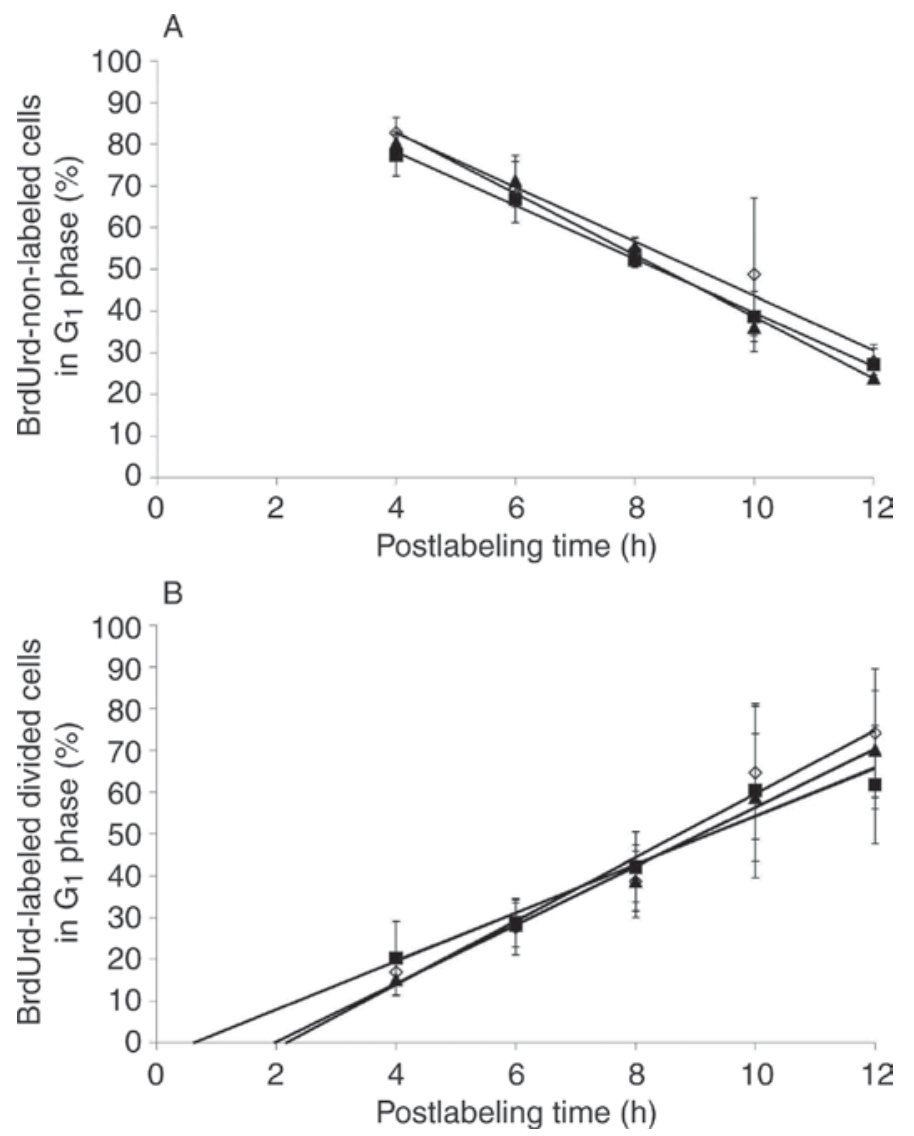

Figure 4. Ubiquitin treatment did not affect the rate of $\mathrm{G}_{1}$ (gap 1)/S (synthesis) transition or the length of $\mathrm{G}_{2}+\mathrm{M}$ (gap $2+$ mitosis) phase in CaCo-2 cells. The lengths of the different cell cycle phases were studied with a bromodeoxyuridine (BrdUrd)-DNA flow cytometric method. Twenty-four hours after seeding, ubiquitin was added to achieve the final concentrations of $0.02(\mathbf{\square})$ or $2.0(\mathbf{\Delta}) \mu \mathrm{mol} / \mathrm{L}$. The control $(\diamond)$ received PBS. Cells were labeled with BrdUrd after $48 \mathrm{~h}$ of ubiquitin treatment. After a 30-min labeling period, the medium containing BrdUrd was removed and the cells were allowed to progress through the cell cycle in BrdUrd-free medium. Cells were collected for flow cytometric-mediated analysis of the DNA and the BrdUrd contents at various times postlabeling. A) The slope of each line indicates the rate of $\mathrm{G}_{1} / \mathrm{S}$ transition (i.e., the steeper the line, the higher the rate of $G_{1} / S$ transition). The data were fit by regression analysis. $B$ ) The intercepts of the lines with the $\mathrm{x}$-axis is a measure of the length of the $\mathrm{G}_{2}+\mathrm{M}$ phase. Values are mean $\pm \mathrm{SD}$ for $\mathrm{n}=6$, from 2 independent experiments. When not visible, bars are covered by the symbol.

intestine and colon), is absent. It is therefore unclear to what extent Ub is degraded by various enzymes present in the intestine and what concentration can be achieved in the intestine. It is also unclear to what extent $\mathrm{Ub}$ in milk taken up in the intestine can contribute to the blood level of Ub.

The short time study showed a small but significant growth inhibitory effect of Ub treatment $(2 \mu \mathrm{mol} / \mathrm{L})$ on CaCo-2 cells. Daino et al. (2000) found a growth inhibitory effect in HL-60 and KT-3 hematopoietic cell lines at concentrations above $1 \mu \mathrm{mol} / \mathrm{L}$, thus in the same concentration range as in the present study.
The mechanism behind the growth inhibition has to be elucidated. Results from the Western blot show an increased expression of cell cycle regulatory proteins involved in progression through $\mathrm{G}_{1}, \mathrm{~S}$, and $\mathrm{G}_{2}$ phases of the cells cycle, whereas the M phase cyclin (cyclin B1) was reduced in cells treated with Ub. Results from cell cycle kinetics, however, seemingly do not agree with this because they point toward a prolongation of the $\mathrm{G}_{1}$ phase. However, it is not the levels of cyclins D1, E1, A2, and B1 that are of importance in cell cycle regulation, but rather their function in activating cyclin-dependant kinases (Johnson and Walker, 1999).

Western blot also revealed an increased level of ubiquitinated proteins in $\mathrm{CaCo}-2$ cells treated with Ub. It has to be clarified whether the extracellular Ub entered the cytoplasm and was bound to intracellular proteins or whether Ub was conjugated to proteins on the cell membrane. However, several studies have shown that extracellular Ub may be incorporated into cells, exerting an intracellular effect (Daino et al., 2000; Majetschak et al., 2006). Studies by Daino et al. (2000) suggested that uptake of extracellular Ub into hematopoietic cells mediated growth suppression. The decrease in growth was implied to be attributable to induced apoptosis by selective degradation of the intracellular protein signal transducer and activator of transcription 3 (STAT3; Daino et al., 2000). In a more recent study, Majetschak et al. (2006) found that extracellular Ub was taken up by monocytic cells and was conjugated to intracellular proteins. This process was affected by inflammatory stimuli (Majetschak et al., 2006).

The long-term studies in CaCo-2 cells were designed to mimic exposure of $\mathrm{Ub}$ from milk in the colon over an extended period of time. The cell counting at each passage revealed that Ub had the same growth inhibitory effect at every passage. Thus, there was not an increasing effect with increased time of Ub treatment as we had observed in previous studies with the bovine milk peptide lactoferricin (Freiburghaus et al., 2009). For the neuroblastoma cell line, the effects on cell proliferation were even more prominent over a longer time span.

The growing knowledge of the relationship between diet and health may reveal novel strategies of cancer prevention through change of eating habits. Over time, small but recurrent doses of bioactive peptides may prevent the carcinogenic process by decreasing the rate of cell proliferation of normal and precancerous cells. Also, small doses of bioactive peptides may reduce the rate of growth of a tumor. The present study on the growth inhibitory effects of Ub on human cancer cell lines together with previous reports on the growth decreasing effects of Ub adds up to the picture of milk and milk products as a health-promoting food source. 
A

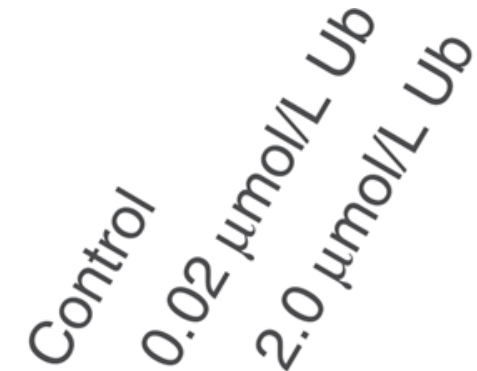

ERK 1/2

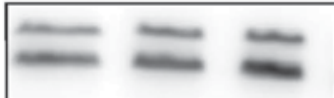

$44 \mathrm{kDa}$

42 kDa

ERK 1/2

(phos)

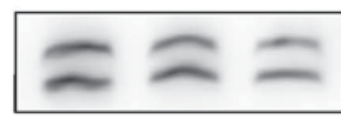

$44 \mathrm{kDa}$

Cyclin D1

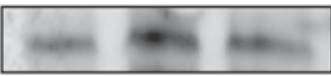

$42 \mathrm{kDa}$

Cyclin E1

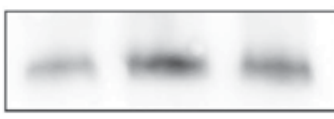

36 kDa

Cyclin A2

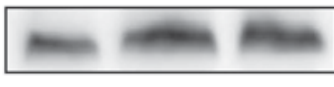

$50 \mathrm{kDa}$

Cyclin B1

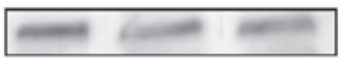

$62 \mathrm{kDa}$

B

\begin{tabular}{lcccc}
\hline & & Control & $\mathbf{0 . 0 2} \boldsymbol{\mu m o l} / \mathbf{L}$ ubiquitin & $\mathbf{2 . 0} \boldsymbol{\mu m o l} / \mathbf{L}$ ubiquitin \\
\hline ERK 1/2 & & & & \\
$44 \mathrm{kDa}(\mathrm{n}=4)$ & $\downarrow$ & 100 & $86 \pm 17$ & $87 \pm 22$ \\
$42 \mathrm{kDa}(\mathrm{n}=4)$ & - & 100 & $97 \pm 13$ & $95 \pm 13$ \\
\hline Phos ERK 1/2 & & & & \\
$44 \mathrm{kDa}(\mathrm{n}=6)$ & $\downarrow$ & 100 & $88 \pm 18$ & $76 \pm 19 * *$ \\
$42 \mathrm{kDa}(\mathrm{n}=6)$ & $\downarrow$ & 100 & $92 \pm 10$ & $74 \pm 17 * *$ \\
\hline Cyclin D1 & & & & \\
$36 \mathrm{kDa}(\mathrm{n}=4)$ & $\uparrow$ & 100 & $152 \pm 40 *$ & $139 \pm 52$ \\
\hline Cyclin E1 & & & & \\
$50 \mathrm{kDa}(\mathrm{n}=4)$ & $\uparrow$ & 100 & $133 \pm 58^{*}$ & $111 \pm 36$ \\
\hline Cyclin A2 & & & & \\
$60 \mathrm{kDa}(\mathrm{n}=4)$ & $\uparrow$ & 100 & $131 \pm 11 * *$ & $153 \pm 24 * *$ \\
\hline Cyclin B1 & & & & \\
$62 \mathrm{kDa}(\mathrm{n}=5)$ & $\downarrow$ & 100 & $80 \pm 20$ & $88 \pm 11 *$ \\
\hline
\end{tabular}

Figure 5. Effect of ubiquitin (Ub) treatment on various cell cycle regulatory proteins in CaCo-2 cells. Twenty-four hours after seeding of cells, Ub was added to achieve the final concentrations of 0.02 or $2.0 \mu \mathrm{mol} / \mathrm{L}$. The control cells received PBS. A) Cells were harvested after 48 $\mathrm{h}$ of Ub treatment and Western blot analysis was used to detect the different proteins. B) The intensities of the bands are presented as percentage of the control. $\mathrm{n}=3$ to 5 independent samples \pm SD. ${ }^{*} P<0.05$ compared with control; ${ }^{* *} P<0.01$ compared with control. ERK1/2 $=$ extracellular signal-regulated kinase $1 / 2$. 


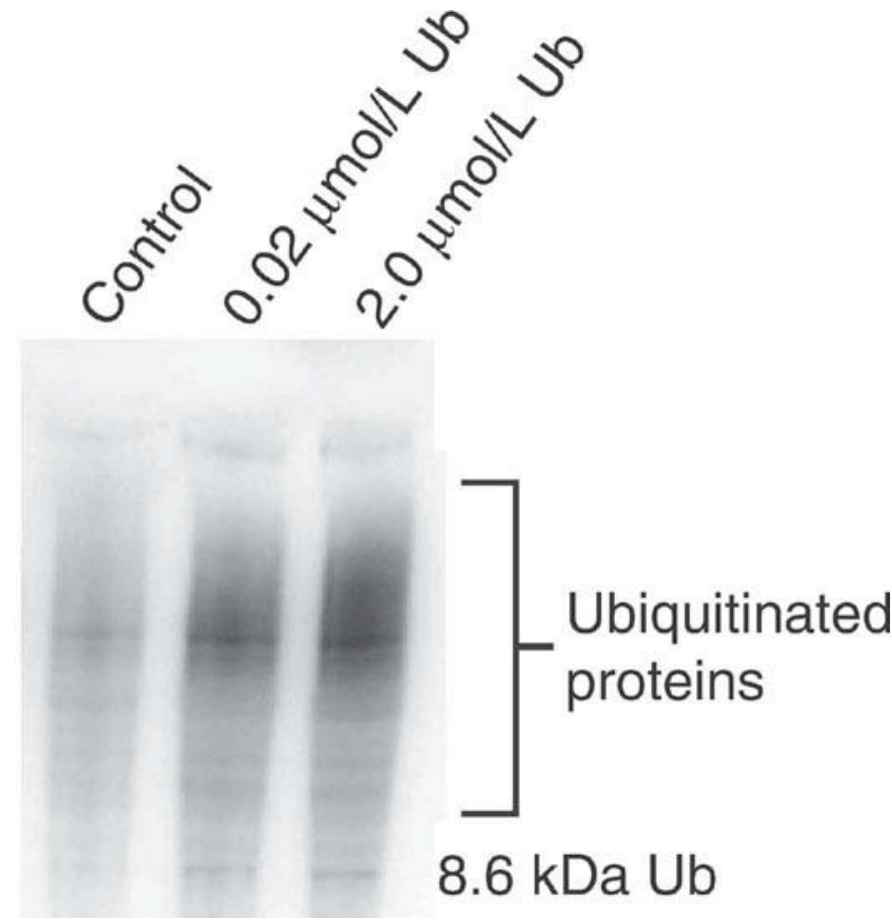

Figure 6. Western blot using antibodies to detect the ubiquination of cellular proteins after $48 \mathrm{~h}$ of ubiquitin (Ub) treatment. The Ub protein is seen as conjugates on the proteins and also as a faint band at $8.6 \mathrm{kDa}$. Representative image shown for $\mathrm{n}=5$.

In general, when investigating bioactive food components, one might consider using animal studies to truly understand the effects of the component in vivo.

\section{CONCLUSIONS}

In the search for unknown peptides in bovine milk, we identified Ub. We then decided to treat human colon cancer CaCo-2 cells with Ub and found that the rate of cell proliferation was slightly reduced at a $0.02 \mu \mathrm{mol} / \mathrm{L}$ concentration, which became significant when the cells were treated for several passages. Studies of cell cycle kinetics pointed to a prolongation of the $G_{1}$ phase by Ub treatment, whereas the $\mathrm{S}$ and $\mathrm{G}_{2}+\mathrm{M}$ phases were unaffected. The rate of cell proliferation of the human neuroblastoma SH-SY5Y cell line was also reduced. Our data point to Ub possibly being one of the components in milk reducing the risk of cancer by reducing the rate of cell proliferation.

\section{ACKNOWLEDGMENTS}

We thank Ewa Dahlberg at the Department of Cell and Organism Biology (Lund University, Sweden) for expert technical assistance. We also thank Bo Baldetorp for the use of the flow cytometer and the MALDI-TOF
MS at the Department of Oncology, Lund University, Sweden. This work was supported by grants from The Swedish Research Council for Environment, Agricultural Sciences and Spatial Planning (FORMAS), Stockholm, Sweden.

\section{REFERENCES}

Baska, K. M., G. Manandhar, D. Feng, Y. Agca, M. W. Tengowski, M. Sutovsky, Y.-J. Yi, and P. Sutovsky. 2008. Mechanism of extracellular ubiquitination in the mammalian epididymis . J. Cell. Physiol. 215:684-696.

Berggård, T., S. Miron, P. Onnerfjord, E. Thulin, K. S. Akerfeldt, J. J. Enghild, M. Akke, and S. Linse. 2002. Calbindin D28k exhibits properties characteristic of a $\mathrm{Ca} 2+$ sensor. J. Biol. Chem. 277:16662-16672.

Cho, E., S. A. Smith-Warner, D. Spiegelman, W. L. Beeson, P. A. van den Brandt, G. A. Colditz, A. R. Folsom, G. E. Fraser, J. L. Freudenheim, E. Giovannucci, R. A. Goldbohm, S. Graham, A. B. Miller, P. Pietinen, J. D. Potter, T. E. Rohan, P. Terry, P. Toniolo, M. J. Virtanen, W. C. Willett, A. Wolk, K. Wu, S. S. Yaun, A. Zeleniuch-Jacquotte, and D. J. Hunter. 2004. Dairy foods, calcium, and colorectal cancer: A pooled analysis of 10 cohort studies. J. Natl. Cancer Inst. 96:1015-1022.

Choi, H. K., W. C. Willett, M. J. Stampfer, E. Rimm, and F. B. Hu. 2005. Dairy consumption and risk of type 2 diabetes mellitus in men: A prospective study. Arch. Intern. Med. 165:997-1003.

Clare, D. A., and H. E. Swaisgood. 2000. Bioactive milk peptides. J. Dairy Sci. 83:1187-1195.

Daino, H., I. Matsumura, K. Takada, J. Odajima, H. Tanaka, S. Ueda, H. Shibayama, H. Ikeda, M. Hibi, T. Machii, T. Hirano, and Y. Kanakura. 2000. Induction of apoptosis by extracellular ubiquitin in hematopoietic cells: Possible involvement of STAT3 degradation by proteasome pathway in interleukin 6-dependent hematopoietic cells. Blood 95:2577-2585.

Elwood, P. C., I. Givens, A. D. Beswick, A. M. Fehily, J. E. Pickering, and J. Gallager. 2008. The survival advantage of milk and dairy consumption: An overview of evidence from cohort studies of vascular diseases, diabetes and cancer . J. Am. Coll. Nutr. 27:723734.

Fong, B. Y., and C. S. Norris. 2009. Quantification of milk fat globule membrane proteins using selected reaction monitoring mass spectrometry. J. Agric. Food Chem. 57:6021-6028.

Fredlund, J. O., M. Johansson, B. Baldetorp, and S. M. Oredsson. 1994. Abnormal DNA synthesis in polyamine deficient cells revealed by bromodeoxyuridine-flow cytometry technique. Cell Prolif. 27:243-256.

Fredlund, J. O., and S. M. Oredsson. 1997. Ordered cell cycle phase perturbations in Chinese hamster ovary cells treated with an $S$-adenosylmethionine decarboxylase inhibitor. Eur. J. Biochem. 249:232-238.

Freiburghaus, C., B. Janicke, H. Lindmark-Månsson, S. M. Oredsson, and M. Paulsson. 2009. Lactoferricin treatment decreases the rate of cell proliferation of a human colon cancer cell line. J. Dairy Sci. 92:2477-2484.

Gill, H. S., and M. L. Cross. 2000. Anticancer properties of bovine milk. Br. J. Nutr. 84:161-166.

Goldstein, G., M. Scheid, U. Hammerling, D. H. Schlesinger, H. D. Niall, and E. A. Boyse. 1975. Isolation of a polypeptide that has lymphocyte-differentiating properties and is probably represented universally in living cells. Proc. Natl. Acad. Sci. USA 72:11-15.

Haug, A., A. T. Høstmark, and O.M. Harstad. 2007. Bovine milk in human nutrition-A review. Lipids Health Dis. 6:1-16.

Hershko, A., and A. Ciechanover. 1992. The ubiquitin system for protein degradation. Annu. Rev. Biochem. 61:761-807.

Hjartåker, A., P. Laake, and E. Lund. 2001. Childhood and adult milk consumption and risk of premenopausal breast cancer in a cohort of 48,844 women-The Norwegian women and cancer study. Int. J. Cancer 93:888-893. 
Janicke, B., G. Önning, and S. M. Oredsson. 2005. Differential effects of ferulic acid and $p$-coumaric acid on $\mathrm{S}$ phase distribution and length of S phase in human colonic cell line Caco-2. J. Agric. Food Chem. 53:6658-6665.

Johnson, D. G., and C. L. Walker. 1999. Cyclins and cell cycle. Annu. Rev. Pharmacol. Toxicol. 39:295-312.

Korhonen, H. 2009. Milk-derived bioactive peptides: From science to applications. J. Functional Foods 1:177-187.

Korhonen, H., and A. Pihlanto. 2006. Bioactive peptides: Production and functionality. Int. Dairy J. 16:945-960.

Liu, S., H. K. Choi, E. Ford, Y. Song, A. Klevak, J. E. Buring, and J E. Manson. 2006. A prospective study of dairy intake and the risk of type 2 diabetes in women. Diabetes Care 29:1579-1584.

Lynch, H. T., and A. de la Chapelle. 2003. Hereditary colorectal cancer. N. Engl. J. Med. 348:919-932.

Mader, J. S., D. Smyth, J. Marshall, and D. W. Hoskin. 2006. Bovine lactoferricin inhibits basic fibroblast growth factor- and vascular endothelial growth factor $165^{-}$induced angiogenesis by competing for heparin-like binding sites on endothelial cells. Am. J. Pathol. 169:1753-1766.

Majetschak, M., N. Ponelies, and T. Hirsch. 2006. Targeting the monocytic ubiquitin system with extracellular ubiquitin. Immunol. Cell Biol. 84:59-65.

Möller, N. P., K. E. Scholz-Ahrens, N. Roos, and J. Schrezenmeir. 2008. Bioactive peptides and proteins from foods: Indication for health effects . Eur. J. Nutr. 47:171-182.
Nasizadeh, S., L. Myhre, L. Thiman, and S. M. Oredsson. 2005 Importance of polyamines in cell cycle kinetics as studied in a transgenic system. Exp. Cell Res. 308:254-264.

Perdigón, G., A. de Moreno de LeBlanc, J. Valdez, and M. Rachid. 2002. Role of yoghurt in the prevention of colon cancer. Eur. J. Clin. Nutr. 56(Suppl. 3):S65-S68.

Schrezenmeir, J., H. Korhonen, M. Williams, H. S. Gill, and N. P. Shah. 2000. Foreword. Br. J. Nutr. 84:1.

Smolenski, G., S. Haines, F. Y. Kwan, J. Bond, V. Farr, S. R. Davis, K. Stelwagen, and T. T. Wheeler. 2007. Characterisation of host defence proteins in milk using a proteomic approach. J. Proteome Res. 6:207-215.

Takada, K., H. Nasu, N. Hibi, Y. Tsukada, T. Shibasaki, K. Fujise, M. Fujimuro, H. Sawada, H. Yokosawa, and K. Ohkawa. 1997. Serum concentrations of free ubiquitin and multiubiquitin chains. Clin. Chem. 43:1188-1195.

Wakabayashi, H., K. Yamauchi, and M. Takase. 2006. Lactoferrin research, technology and applications. Int. Dairy J. 16:12411251.

World Cancer Research Fund/American Institute for Cancer Research. 2007. Food, Nutrition, Physical Activity and the Prevention of Cancer: A Global Perspective. AICR, Washington, DC. 